\title{
Rethinking marketing: back to purpose
}

\author{
Julia A. Fehrer ${ }^{1,2}$ \\ Published online: 2 December 2020 \\ (C) Academy of Marketing Science 2020
}

\begin{abstract}
Key and colleagues raise some serious criticisms related to the marketing discipline's purpose drift and short-sighted approach to rigor and relevance. They provide a comprehensive and nuanced picture of the grand challenges in marketing, including the loss of domain expertise, detachment from real-world phenomena, nurturing of methodological monocultures and more generally a perception problem in academia and management practice. This commentary complements their assessment by reviewing strands of literature in the niches and at the edge of mainstream marketing, where we may find some solutions or at least seeds for solutions as a starting point to refine, recalibrate and potentially reshape the future of marketing and marketing research.
\end{abstract}

Keywords Marketing myopia $\cdot$ Grand challenges $\cdot$ Systems thinking $\cdot$ Value cocreation $\cdot$ Market shaping

\section{Introduction}

The article 'Marketing's theoretical and conceptual value proposition: opportunities to address marketing's influence', written by Thomas Martin Key, Terry Clark, OC Ferrell, David W. Steward and Leyland Pitt, raises the fundamental question about the purpose of marketing. Aligned with other critical voices (such as Webster and Lusch 2013; Möller et al. 2020; Yadav 2010; Jaworski and Kohli 2017), the authors alert the marketing research community to the need for a radical revision of how we conceptualize, study, and apply marketing. They point to four interrelated problems: 1) loss of domain expertise, 2) detachment from real-world phenomena (see also, Möller et al. 2020; Nenonen et al. 2017; Webster and Lusch 2013), 3) nurturing of methodological monocultures (see also Hunt 2018; McAlister 2016; Jaworski and Kohli 2017; Zeithaml et al. 2020) and, 4) detachment from the discipline's value proposition and purpose. I believe that this debate offers great opportunities to refine, recalibrate and potentially reshape the future of marketing and marketing

Julia A. Fehrer

j.fehrer@auckland.ac.nz

1 The University of Auckland Business School, Owen G Glenn Building, 12 Grafton Road, Auckland, New Zealand

2 University of Bayreuth, Bayreuth, Germany research and, as an emergent scholar, I feel deeply honored to contribute to this debate.

While I agree with the important issues raised by eminent scholars in our discipline and recognize similar discussions in my home turf-the Australasian and European marketing research communities, I will argue that some solutions, or at least seeds for solutions may be right in front of us, in the niches of our discipline and at the edge of mainstream marketing. More specifically, I will point to system theories, growing with and out of (S-D logic), which provide a range of marketing frameworks and midrange theories (Brodie et al. 2011; Vargo and Lusch 2017) that acknowledge and embrace the marketing discipline's diversity. Further, the field of business and industrial marketing presents an extensive and fastgrowing knowledge base to address some of the complexity in contemporary marketing environments (Möller et al. 2020). At the interface of service research, information systems and design, we may find methods that embrace the inherently complex and reflexive nature of many marketing tasks. Finally, transformative service research, macro marketing and sustainable marketing research might support with recalibrating the discipline's purpose.

Key et al. (2020) provide a comprehensive and nuanced picture of the grand challenges in marketing as a way forward to shape the future of our discipline. In the remainder, I will work with four of the authors central observations as a starting point to build an inventory of what our discipline may have to offer when we strengthen research at the edge of mainstream 
marketing and allow for more plurality, theories-in-use, and transdisciplinary research.

\section{Observation 1: Need for re-claiming domain expertise related to broader marketing systems}

\author{
"Examining our history indicates great diversity in the \\ discipline's contributions to all parts of the marketing \\ system," (OC Ferrell in Key et al. 2020, page 3).
}

Key et al. (2020) remind us of the roots of marketing as an applied economic science with a broader focus than 'just' the customer, and advocate for theory development connected to the broader marketing system. The authors refer to S-D logic as one of the few indigenous marketing theories that offers an encompassing systemic framework of what historically has been at the center of the marketing domain-markets and value (co-) creation (Vargo and Lusch 2004, 2008, 2016).

Indeed, one of Vargo and Lusch's (2004) motivations for developing S-D logic was to provide an integrative perspective of divergent strands of thinking that had been occurring in the marketing discipline since the 1980s, including market orientation (Kohli and Jaworski 1990; Narver and Slater 1990), services and relationship marketing (Zeithaml et al. 1985; Grönroos 1994; Gummesson 1994), quality management (Parasuraman et al. 1993), value and supply chain management (Normann and Ramirez 1993), resource management and competitive advantage (Constantin and Lusch 1994; Hunt and Morgan 1995). The foundations of S-D logic are anchored in social and economic processes, informed by systems thinking (e.g., Alderson 1957), strategic thinking about markets (Barney 1991; Teece 2007), and collaborative value cocreation (Normann and Ramirez 1993; Prahalad and Ramaswamy 2004). S-D logicdiscussed and nurtured in a niche marketing community of interdisciplinary service researchers-has become an important theoretical backbone of our discipline (Pohlmann and Kaartemo 2017; Brodie et al. 2019).

S-D logic thought, as it advanced, created further promising offspring and blends of marketing frameworks and midrange theories (Brodie et al. 2011) that acknowledge and embrace the marketing discipline's diversity. This includes conceptual developments and vectors of diffusion (Vargo and Lusch 2017) in the fields of open and technological innovation (Lusch and Nambisan 2015; Vargo et al. 2020), sales (Hartmann et al. 2018); market-shaping capabilities (Nenonen et al. 2019), systemic business models (Wieland et al. 2017), and service ecosystems (Vargo and Lusch 2016).
As Vink et al. (2020) point out, a service ecosystem view not only provides a more systemic and holistic understanding of value co-creation, but also offers important insights into how firms, policymakers, entrepreneurs and other actors are able to influence value co-creation through designing the service ecosystems of which they are part. Service ecosystems exhibit qualities of emergence and are therefore beyond the control of any individual actor (Chandler et al. 2019). Nevertheless, actors are able to intentionally influence (i.e., design), at least partially (e.g., through reconfiguring institutional arrangements; Koskela-Huotari et al. 2016; Vargo et al. 2015) how ecosystems evolve (Mele et al. 2018). Service ecosystem thinking thus offers great potential to address some of the 'wicked problems' posed by digital disruption, ecological and social sustainability challenges.

Another particularly promising conceptual development to understand complex and emergent market and marketing dynamics is provided by recent work on market-shaping (Nenonen et al. 2019; Baker et al. 2019). Market-shaping takes a market systems view (e.g., Maciel and Fischer 2020; Nenonen et al. 2019; Jaworski et al. 2020; Vargo et al. 2017) and offers strategies of how organizations and other actors, including customers (Dolbec and Fischer 2015); B2B buyers (Ulkuniemi et al. 2015), activists (Rao 2009), and policymakers (Kaartemo et al. 2020), can deliberately influence market change. In sum, systemic frameworks building on S-D logic, service ecosystems and market-shaping may offer a portfolio of concepts to (re-)claim domain expertise in market and marketing systems. Arguably, such systemic frameworks may also help to (re-)connect marketing theory closer with real-world phenomena and strategy.

\section{Observation 2: Need for stronger attachment to real-world phenomena}

\begin{abstract}
"Marketing as a practice, despite its visibility, gets ignored by other business practitioners; marketing, as an academic discipline, gets ignored by other business disciplines. As a marketing scholar, I contend that marketing gets ignored, because it ignores many important and interesting things that really matter" (Leyland Pitt in Key et al. 2020, page 6).
\end{abstract}

Key et al. (2020) argue, aligned with Hunt (2018), that academic marketing research is too much focused on solving micro-level and non-strategic issues leading to a chasm between how marketing academics study the business environment and how the new business reality actually unfolds. 
A similar argument runs in the marketing niche of business and industrial marketing. Möller et al. (2020) demonstrate, in their recently published positioning paper, highly cited contemporary managerial writing reveals how underlying megatrends-digitalization, globalization, and environmental awareness in particular-render today's business reality inherently systemic, complex, and volatile. Like Key et al. (2020), the authors point to the pressing need for marketing academe to theorize about such complex business environments. In their literature review, Möller et al. (2020) show that various streams in business marketing research are already tackling the complex contemporary business environments that managers face. These strands of research offer strategic marketing approaches drawing on business, service and innovation ecosystems (e.g., Aarikka-Stenroos and Ritala 2017), including, for example, strategies for network orchestration, network management and network capabilities (e.g., Perks et al. 2017; Nordin et al. 2018).

The field of strategic (business) marketing presents an extensive and fast-growing knowledge base to address some of the complexity in contemporary business environments. At the same time, as suggested by Key et al. (2020) and Möller (2020), we need to make such knowledge bases more accessible for broader academic audiences and, potentially even more importantly, for managers and policymakers though an academic language that requires less disciplinary proficiency. Further, as emphasized by Key et al. (2020), to embrace the complex and systemic nature of contemporary business environments, we need more plurality in research methods (Brodie et al. 2019), a stronger focus on longitudinal and qualitative (action) research (Brodie and Peters 2020) and more appreciation for theories-in-use, developed in the field by and together with managers (Zeithaml et al. 2020; Nenonen et al. 2017).

\section{Observation 3: Need for cross-fertilizing research methods}

Terry Clark highlights three reasons why "marketing is indeed in trouble [...] 1) Marketing's illusions of well-structured problems; 2) Marketing's illusion of technique (method); and 3 ) the essentially reflexive nature of Marketing's task. [...] In combination, these three collude (as it were), to produce a paradoxical situation, in which while a field develops greater and greater methodological sophistication, it simultaneously becomes more marginalized. In other words, the question becomes, are we finessing our way to irrelevance?" (Key et al. 2020, page 9). Key et al. (2020, p.11) conclude, that most marketing problems (in particular the interesting ones) are in fact 'ill-structured' and request a broader "methodological apparatus."

The marketing discipline (and any other social and economic science) indeed is confronted with two types of problems-difficult problems and wicked problems (Rittel and Webber 1973). Difficult problems are challenging but can be solved over time by applying and refining standard techniques. For example, developing a vaccine for COVID19 is a hard, but ordinary, problem that virologists can solve over time by applying standard techniques of experimenting and testing. In contrast, wicked problems have innumerable causes, are tough to describe, and do not have straightforward right or wrong answers (Rittel and Webber 1973). Preventing our social and economic systems from collapsing due to the pressure caused by COVID-19 is a wicked problem with multiple causes and no one right way forward, as can be seen in the different approaches adopted by countries to tackle the problem.

Arguably, both types of problems-difficult and wicked-are relevant and worthwhile to address, however, there is a strong tendency in marketing practice and academia to overemphasize the relevance of difficult problems by working with vast amounts of data and advanced statistical models (Camillus 2008). A stronger focus on theory discovery (Yadav 2010) and explorative approaches that help managers, policymakers, and scholars to better cope with wicked problems could be one way forward to gain greater impact as a discipline. Van Burg et al. (2020), for example, urge management researchers to leverage the plurality of different qualitative approaches, including less conventional methods such as netnography, autoethnography, qualitative comparative analysis (QCA), abductive reasoning, and action research, to accumulate knowledge of complex and intriguing phenomena that are unfolding in today's world. Further promising approaches are from design science and action design research (Hevner et al. 2004; Sein et al. 2011), which follow research processes that accept the contained, inseparable, inherently interwoven activities of building a method or conceptual artifact while intervening in an organization. These and similar methods embrace the inherently complex and reflexive nature of many marketing tasks and-balanced with more conventional methods-may have some potential to recalibrate rigor and relevance.

\section{Observation 4: Need for rethinking the value and purpose of marketing}

\author{
"Indeed, as a discipline, marketing has been strangely \\ silent about the value it adds" (David Steward in Key \\ et al. 2020, page 12).
}

Key et al. (2020) argue that marketing has a perception problem and refer to two important issues. First, marketing does a poor job of explaining how it creates value in financial terms, 
and second, marketing scholars can do a better job of showing the discipline's contribution to society.

Similarly, in marketing practice we see a decline in marketing's influence. For example, for the last decade the number and influence of the CMO (Chief Marketing Officer) is decreasing. However, in parallel, CDOs (Chief Digital Officers) are on the rise. This new cross-functional role is a blend of CMO, CFO (Chief Financial Officer), and CIO (Chief Information Officer). CDOs are concerned with implementing digital initiatives that enable strategic innovation and business transformation (The Leadership Network 2018). Their initiatives are measured by the value created by their digital projects and digital marketing campaigns in terms of improving customer engagement, sales conversion rates, impressions, and many more measures. Further, these measures are monitored in real-time and linked to enterprise KPIs with the goal of demonstrating positive impact. There has been a notable shift in marketing practice toward digital marketing and digital marketing analytics for nearly two decades, reflected in changing budget allocations and organizational structures (Statista 2020). However, this shift is still not yet reflected in marketing academia-either in research or education. A Scopus database search (in September 2020) reveals only ten articles published in quality marketing outlets on digital marketing strategies. This niche of (strategic) digital marketing research shows substantial potential to closely link marketing to financial value creation and practical relevance.

Finally, Key et al. (2020) state: "Marketing should be inclusive and encourage diversity in theory and research for managerial, societal, and public policy domains" (page 3). As marketing academia entered the twenty-first century, a stream of transformative consumer and service researchers began to question whether the discipline's focus on managerially relevant outcomes, such as customer satisfaction, loyalty, behavioral intention, word-of-mouth and so forth, had truly enhanced people's lives and societal well-being (RussellBennett et al. 2019). The emerging research stream of transformative service research, concerned with enhancing societal welfare and quality of life for all beings (Ostrom et al. 2010), is inspired by transformative consumer research, which seeks to "solve real [consumer] problems" (Mick 2006, p.1) by applying marketing principles to enhance the lives of individuals and communities. Contemporary topics in transformative service research include highly relevant societal issues like service inclusion (Fisk et al. 2018) and vulnerable consumers (Rosenbaum et al. 2017). This, and related work in the field of sustainability, macro and social marketing research, offer a broader view of value creation including economic growth, social progress, and environmental stewardship. In so doing, these approaches present a way forward in refining the purpose of the marketing discipline.

\section{Conclusion}

I would like to commend Key and colleagues for their critical, much needed and eye-opening reflection on the grand challenges of our discipline. This collection of essays gives a rich and nuanced historical review of, and outlook for, marketing research. The time is ripe for a more fundamental course correction and this can only be done with eminent scholars raising their voices. I endorse their efforts and conclusions. With my commentary, I build on these efforts by highlighting issues related to both topics and methodologies in marketing and show some of the developments at the edge and in the niches of our discipline. Social network theory argues that actors that operate at the edge of a system have the greatest chance of creating innovation (Granovetter 1983). Thus, nurturing research that goes beyond mainstream marketing and builds ties to other disciplines might be a promising way out of shortsighted approaches to rigor and relevance. By no means is my review of upcoming and innovative research fields comprehensive. Hence, I hope other scholars complement this review to further develop an inventory of what our discipline and other related disciplines have to offer to address some of the grand challenges raised by Key et al. (2020).

\section{References}

Alderson, W. (1957). Marketing behavior and executive action: A functionalist approach to marketing theory. Homewood: Irwin.

Aarikka-Stenroos, L., \& Ritala, P. (2017). Network management in the era of ecosystems: Systematic review and management framework. Industrial Marketing Management, 67, 23-36.

Baker, J. J., Storbacka, K., \& Brodie, R. J. (2019). Markets changing, changing markets: Institutional work as market shaping. Marketing Theory, 19(3), 301-328.

Barney, J. (1991). Firm resources and sustained competitive advantage. Journal of Management, 17(1), 99-120.

Brodie, R. J., Löbler, H., \& Fehrer, J. A. (2019). Evolution of servicedominant logic: Towards a paradigm and metatheory of the market and value cocreation? Industrial Marketing Management, 79, 3-12.

Brodie, R. J., Saren, M., \& Pels, J. (2011). Theorizing about the service dominant logic: The bridging role of middle range theory. Marketing Theory, 11(1), 75-91.

Brodie, R. J., \& Peters, L. D. (2020). New directions for service research: Refreshing the process of theorizing to increase contribution. Journal of Services Marketing, 34(3), 415-428.

Camillus, J. C. (2008). Strategy as a wicked problem. Harvard Business Review, 86(5), 98.

Chandler, J. D., Danatzis, I., Wernicke, C., Akaka, M. A., \& Reynolds, D. (2019). How does innovation emerge in a service ecosystem? Journal of Service Research, 22(1), 75-89.

Constantin, J. A., \& Lusch, R. F. (Eds.). (1994). Understanding resource management. Oxford, $\mathrm{OH}$ : The Planning Forum.

Dolbec, P. Y., \& Fischer, E. (2015). Refashioning a field? Connected consumers and institutional dynamics in markets. Journal of Consumer Research, 41(6), 1447-1468.

Fisk, R. P., Dean, A. M., Alkire, L., Joubert, A., Previte, J., Robertson, N., \& Rosenbaum, M. S. (2018). Design for service inclusion: Creating 
inclusive service systems by 2050. Journal of Service Management, 29(5), 834-858.

Grönroos, C. (1994). From marketing mix to relationship marketing: Towards a paradigm shift in marketing. Asia-Australia Marketing Journal, 2(1), 9-29.

Granovetter, M. (1983). The strength of weak ties: A network theory revisited. Sociological Theory, 1, 201-233.

Gummesson, E. (1994). Broadening and specifying relationship marketing. Asia-Australia Marketing Journal, 2(1), 31-43.

Hartmann, N. N., Wieland, H., \& Vargo, S. L. (2018). Converging on a new theoretical foundation for selling. Journal of Marketing, 82(2), $1-18$.

Hevner, A. R., March, S. T., Park, J., \& Ram, S. (2004). Design science in information systems research. MIS Quarterly, 28(1), 75-105.

Hunt, S. D. (2018). The prospects for marketing strategy and the marketing discipline in era $\mathrm{V}$ : Is the prognosis promising or problematic? Journal of Marketing Management, 34(1-2), 86-95.

Hunt, S. D., \& Morgan, R. M. (1995). The comparative advantage theory of competition. Journal of Marketing, 59(2), 1-15.

Jaworski, B. J., \& Kohli, A. K. (2017). Conducting field-based, discovery-oriented research: Lessons from our market orientation research experience. AMS Review, 7(1-2), 4-12.

Jaworski, B. J., Kohli, A. K., \& Sarin, S. (2020). Driving markets: A typology and a seven-step approach. Industrial Marketing Management, 91, 142-151.

Kaartemo, V., Nenonen, S., \& Windahl, C. (2020). Institutional work by market-shaping public actors. Journal of Service Theory and Practice.

Key, T. M., Clark, T., Ferrell, O. C., Stewart, D. W., \& Pitt, L. (2020). Marketing's theoretical and conceptual value proposition: Opportunities to address marketing's influence. AMS Review, 1-17.

Kohli, A. K., \& Jaworski, B. J. (1990). Market orientation: The construct, research propositions, and managerial implications. Journal of Marketing, 54(2), 1-18.

Koskela-Huotari, K., Edvardsson, B., Jonas, J. M., Sörhammar, D., \& Witell, L. (2016). Innovation in service ecosystems - Breaking, making, and maintaining institutionalized rules of resource integration. Journal of Business Research, 69(8), 2964-2971.

Lusch, R. F., \& Nambisan, S. (2015). Service innovation: A servicedominant logic perspective. MIS Quarterly, 39(1), 155-176.

Maciel, A. F., \& Fischer, E. (2020). Collaborative market driving: How peer firms can develop markets through collective action. Journal of Marketing, 0022242920917982.

McAlister, L. (2016). Rigor versus method imperialism. Journal of the Academy of Marketing Science, 44(5), 565-567.

Mele, C., Nenonen, S., Pels, J., Storbacka, K., Nariswari, A., \& Kaartemo, V. (2018). Shaping service ecosystems: Exploring the dark side of agency. Journal of Service Management, 29(4), 521545 .

Mick, D. G. (2006). Meaning and mattering through transformative consumer research. Advances in Consumer Research, 33(1), 1-4.

Möller, K., Nenonen, S., \& Storbacka, K. (2020). Networks, ecosystems, fields, market systems? Making sense of the business environment. Industrial Marketing Management, 90, 380-399.

Narver, J. C., \& Slater, S. F. (1990). The effect of a market orientation on business profitability. Journal of Marketing, 54(4), 20-35.

Normann, R., \& Ramirez, R. (1993). From value chain to value constellation: Designing interactive strategy. Harvard Business Review, 71(4), 65-77.

Nenonen, S., Brodie, R. J., Storbacka, K., \& Peters, L. D. (2017). Theorizing with managers: How to achieve both academic rigor and practical relevance? European Journal of Marketing, 51(7/8), $1130-1152$

Nenonen, S., Storbacka, K., \& Windahl, C. (2019). Capabilities for market-shaping: Triggering and facilitating increased value creation. Journal of the Academy of Marketing Science, 47(4), 617-639.
Nordin, F., Ravald, A., Möller, K., \& Mohr, J. J. (2018). Network management in emergent high-tech business contexts: Critical capabilities and activities. Industrial Marketing Management, 74, 89-101.

Ostrom, A. L., Bitner, M. J., Brown, S. W., Burkhard, K. A., Goul, M., Smith-Daniels, V., Demirkan, H., \& Rabinovich, E. (2010). Moving forward and making a difference: Research priorities for the science of service. Journal of Service Research, 13(1), 4-36.

Parasuraman, A., Berry, L. L., \& Zeithaml, V. A. (1993). More on improving service quality measurement. Journal of Retailing, 69(1), $140-147$.

Prahalad, C. K., \& Ramaswamy, V. (2004). Co-creation experiences: The next practice in value creation. Journal of Interactive Marketing, 18(3), 5-14.

Perks, H., Kowalkowski, C., Witell, L., \& Gustafsson, A. (2017). Network orchestration for value platform development. Industrial Marketing Management, 67, 106-121.

Pohlmann, A., \& Kaartemo, V. (2017). Research trajectories of servicedominant logic: Emergent themes of a unifying paradigm in business and management. Industrial Marketing Management, 63, 53-68.

Rao, H. (2009). Market rebels and radical innovation. The McKinsey Quarterly, 1-9.

Rittel, H. W., \& Webber, M. M. (1973). Dilemmas in a general theory of planning. Policy Sciences, 4(2), 155-169.

Russell-Bennett, R., Fisk, R. P., Rosenbaum, M. S., \& Zainuddin, N. (2019). Commentary: Transformative service research and social marketing-converging pathways to social change. Journal of Services Marketing, 33(6), 633-642.

Rosenbaum, M. S., Seger-Guttmann, T., \& Giraldo, M. (2017). Commentary: Vulnerable consumers in service settings. Journal of Services Marketing, 31(4/5), 309-312.

Sein, M. K., Henfridsson, O., Purao, S., Rossi, M., \& Lindgren, R. (2011). Action design research. MIS Quarterly, 35(1), 37-56.

Statista (2020). Change in digital marketing spending and traditional advertising according to CMOs in the United States from 2012 to 2020. Retrieved from https://www.statista.com/statistics/693449/ digital-vs-traditional-marketing-budget-change-according-to-cmosusa/ (September 21 2020).

Teece, D. J. (2007). Explicating dynamic capabilities: The nature and microfoundations of (sustainable) enterprise performance. Strategic Management Journal, 28(13), 1319-1350.

The Leadership Network (2018). The Rise and Role of the Chief Digital Officer. Retrieved from https://theleadershipnetwork.com/article/ the-rise-and-role-of-the-chief-digital-officer (September 21 2020).

Ulkuniemi, P., Araujo, L., \& Tähtinen, J. (2015). Purchasing as marketshaping: The case of component-based software engineering. Industrial Marketing Management, 44, 54-62.

Van Burg, E., Cornelissen, J., Stam, W., \& Jack, S. (2020). Advancing qualitative entrepreneurship research: Leveraging methodological plurality for achieving scholarly impact. Entrepreneurship: Theory and Practice, 00, 1-18.

Vargo, S. L., Akaka, M. A., \& Wieland, H. (2020). Rethinking the process of diffusion in innovation: A service-ecosystems and institutional perspective. Journal of Business Research, 116, 526-534.

Vargo, S. L., \& Lusch, R. F. (2004). Evolving to a new dominant logic for marketing. Journal of Marketing, 68(1), 1-17.

Vargo, S. L., \& Lusch, R. F. (2008). Service-dominant logic: Continuing the evolution. Journal of the Academy of Marketing Science, 36(1), 1-10.

Vargo, S. L., \& Lusch, R. F. (2016). Institutions and axioms: An extension and update of service-dominant logic. Journal of the Academy of Marketing Science, 44(1), 5-23.

Vargo, S. L., \& Lusch, R. F. (2017). Service-dominant logic 2025. International Journal of Research in Marketing, 34(1), 46-67.

Vargo, S. L., Koskela-Huotari, K., Baron, S., Edvardsson, B., Reynoso, J., \& Colurcio, M. (2017). A systems perspective on marketstoward a research agenda. Journal of Business Research, 79, 260268. 
Vargo, S. L., Wieland, H., \& Akaka, M. A. (2015). Innovation through institutionalization: A service ecosystems perspective. Industrial Marketing Management, 44, 63-72.

Vink, J., Koskela-Huotari, K., Tronvoll, B., Edvardsson, B., \& WetterEdman, K. (2020). Service ecosystem design: Propositions, process model, and future research agenda. Journal of Service Research, XX, 1-19. https://doi.org/10.1177/1094670520952537.

Webster, F. E., \& Lusch, R. F. (2013). Elevating marketing: Marketing is dead! Long live marketing! Journal of the Academy of Marketing Science, 41(4), 389-399.

Wieland, H., Hartmann, N. N., \& Vargo, S. L. (2017). Business models as service strategy. Journal of the Academy of Marketing Science, 45(6), 925-943.
Yadav, M. S. (2010). The decline of conceptual articles and implications for knowledge development. Journal of Marketing, 74(1), 1-19.

Zeithaml, V. A., Jaworski, B. J., Kohli, A. K., Tuli, K. R., Ulaga, W., \& Zaltman, G. (2020). A theories-in-use approach to building marketing theory. Journal of Marketing, 84(1), 32-51.

Zeithaml, V. A., Parasuraman, A., \& Berry, L. L. (1985). Problems and strategies in services marketing. Journal of Marketing, 49(2), 3346.

Publisher's note Springer Nature remains neutral with regard to jurisdictional claims in published maps and institutional affiliations. 